\title{
Role of the egg parasitoid, Trichogramma evanescens West., release and silica applications in controlling of the stem borer, Chilo agamemnon Bles. (Lepidoptera: Crambidae), in rice fields in Egypt
}

\author{
A. S. Hendawy ${ }^{1 *}$, M. R. Sherif ${ }^{2}$, A. A. El-Sayed ${ }^{3}$, A. M. Omar ${ }^{3}$ and A. S. Taha ${ }^{2}$
}

\begin{abstract}
Rice, (Oryza sativa L.), is liable to infestation with several insect pests, from which is the rice stem borer, Chilo agamemnon Bles. (Lepidoptera: Crambidae). Field trials were conducted in Egypt during 2015 and 2016 rice seasons to evaluate the efficacy of releasing the egg parasitoid, Trichogramma evanescens Westwood and applying different silica materials to reduce the pest infestation. The most efficient borer control was achieved when the parasitoid was released twice (each at 30,000 wasps/feddan) at Sakha, Gemmiza, and Sirw Agricultural Research Stations in 2015 season, at the maximum tillering stage plus at panicle initiation, as the borer infestation was reduced by $(84.77 \%)$. Similar results $(79.32 \%$ borer control) were obtained when the parasitoid was released at panicle initiation and heading rice plant growth stages. The parasitoid release was as efficient as the application of the widely applied insecticide (carbofuran). A large-scale release (17-20 feddans) was performed at the same research stations in the 2016 season. The parasitoid was released twice (each at 30,000 parasitoids/feddan) at the maximum tillering stage, 30 days after transplanting (DAT) and at panicle initiation (45 DAT). Dead hearts (DH) averaged (1.80 and 3.67\%) in release and non-release treatments, respectively, with a reduction in $\mathrm{DH}$ of (50.95\%). The corresponding reduction in white heads averaged (70.64\%). Potassium silicate (68\% Si, $500 \mathrm{~kg} / \mathrm{feddan})$, as basal after last tillage or magnesium silicate (62\% Si, $2 \mathrm{~kg} /$ feddan), as a spray 20 and 40 days after transplanting achieved (58.25 and 45.31\%) white head reduction, respectively, due to borer infestation.
\end{abstract}

Keywords: Rice, Chilo agamemnon Bles., Trichogramma evanescens, Release, Silica applications, Pest control

\section{Background}

Rice (Oryza sativa L.) is an essential food crop for about one half of the world's population, particularly to Southeast Asian countries. In Egypt, rice shares wheat to satisfy the population requirements of cereals. This crop is liable to infestations with several insect pests, from which is the rice stem borer, Chilo agamemnon Bles. (Lepidoptera: Crambidae) that causes yield losses in case of its high population density. Thus, the growers are worried about the borer's infestation, whatever the economic injury level is (Sherif and

\footnotetext{
* Correspondence: ashendawy@gmail.com

'Plant Protection Research Institute, Agricultural Research Center, Giza, Egypt Full list of author information is available at the end of the article
}

El-Hefny 2014). The misuse applications of insecticides pollute the environment and destroy the natural enemy balance.

The egg parasitoids, Trichogramma spp., are common to parasitize eggs of too many lepidopteran insect species. The eggs of yellow rice stem borer, Scirpophaga incertulas (Walker), was parasitized by Trichogramma japonica with 7-14\% (Marub 1993). Asaady and Navai (1995) released T. japonica in rice fields and recorded $12-32 \%$ egg parasitism of the white rice stem borer. In Egypt, Sherif et al. (2008) recorded about $70 \%$ control of the rice stem borer C. agamemnon due to inundative release of T. evanescens West. 
For the crop yield, about $11-12 \%$ increase was achieved due to the release of $T$. japonicum, which parasitized the eggs of the rice stem borers (Asaady and Navai 1995 and Riba and Sarma 2006).

Monocotyledons accumulate large amounts of silica in their tissues, from which rice accumulates about $12 \%$ silica in straw. Thus, large supplies of silica are required for better crop performance against biotic and abiotic stresses (Nayar et al. 1982). Silica deposition in rice plant tissues increases the rigidity and strength of the culms, which enhances plant resistance to lodging (Vasanthi et al. 2014). On the other hand, Tisdale et al. (1985) pointed out that silica accumulation in tissues increases photosynthesis, due to the erect leaves that are more exposed to sunlight. Vasanthi et al. (2014) reported that the resistance of rice plants to stem borer increases by applying silica to the soil. The mechanism by which silica deposits control invading insects was explained by Chandramani et al. (2010) as wearing of insect mandibles, which results in weak feeding ability and may cause high insect mortality.

The present study was conducted to estimate the appropriate timing of $T$. evanescens releases for controlling the stem borer, C. agamemnon, and for testing different silica materials in rice fields to reduce the pest infestation.

\section{Materials and methods}

Experiments were conducted in rice fields at Sakha, Gemmiza, and Sirw Agricultural Research Stations, Delta, Egypt, in 2015 and 2016 rice seasons.

\section{Cultural practices}

All recommended cultural practices were applied until harvest, without applying chemical control in the experimental areas.

\section{The egg-parasitoid, Trichogramma evanescens}

The egg-parasitoid was obtained from Biological Control Laboratory, established at Rice Research and Training Center, Sakha Agricultural Research Station, Kafr El-Sheikh, Egypt. The parasitoid was reared on eggs of the cereal moth, Sitotroga cerealella Oliver and released at late pupal stage. The parasitized eggs of the host were glued onto paper cards, each containing about 1000 eggs. The releases were practiced just before sunset, and the paper cards, containing S. cerealella parasitized eggs, were hanged on the rice plants using strings. The rate of release was 30,000 wasps/feddan.

\section{Treatments}

In 2015 rice season, the parasitoid was released in two plots, occupied a total area of about 8 feddans (as $4000 \mathrm{~m}^{2}$ per treatment). An area of about $20 \mathrm{~m}$ width along the length of the experimental plot was left without releases to separate between the two treated plots. Treatments and dates of the parasitoid releases are listed in (Table 1). Three weeks before rice harvest, four random samples of rice hills were collected from each treatment, each contains 100 rice hills. The total number of rice tillers and tillers having white head symptom was counted and used to calculate the percentage of white head infestation.

\section{Large-scale release}

In 2016 rice season, the parasitoid was released on a relatively large scale at Sakha, Gemmiza, and Sirw Agricultural Research Stations; treated areas were 20, 15, and 17 feddans, respectively, at the rate of 30,000 parasitoids/feddan. The experimental areas, at the three locations, were sown by Giza 178 rice cultivar. Percentages of dead heart infestations were assessed 45 days after transplanting, and white heads were assessed 3 weeks before harvest. At each assessment, four samples (100 hills each) were collected randomly to represent the infestation rate per feddan.

\section{Silica treatments}

Different silica materials tested in the present study were kindly provided by Al-Ahram Mining Company, Cairo, Egypt. The silica materials applied were:

- Check (without silica)

- Compost straw, 7\% Si, at $2.1 \mathrm{t} /$ feddan as basal after last tillage

- Mixed minerals, $38 \% \mathrm{Si}, 500 \mathrm{~kg} /$ feddan as basal after last tillage.

- Potassium silicate, $68 \% \mathrm{Si}, 500 \mathrm{~kg} /$ feddan as basal after last tillage

- Biocide ore, $46 \% \mathrm{Si}, 2 \mathrm{~kg} /$ feddan as a spray 20 and 40 days after transplanting.

- Magnesium silicate, $62 \% \mathrm{Si}, 2 \mathrm{~kg} /$ feddan as a spray 20 and 40 days after transplanting.

This experiment was conducted in two seasons; 2015 and 2016. The permanent rice field was prepared as recommended and transplanted by Giza 178 rice cultivar on 1 June. The completely randomized block design, with four replicates, was followed. Normal dose of nitrogen (69 kg N/feddan) was applied. Percentage of white heads was assessed 3 weeks before harvest.

\section{Statistical analysis}

Data were subjected to analysis of variance and different means were compared by Duncan (1955). 
Table 1 Schedule of Trichogramma evanescens release (30,000 wasps/feddan) for control of the rice stem borer, Chilo agamemnon, in rice fields, 2015 season

\begin{tabular}{|c|c|c|c|c|}
\hline \multicolumn{3}{|l|}{ Release treatment } & \multicolumn{2}{|c|}{ White head } \\
\hline Date & Days after transplanting (DAT) & Plant growth stages & $\%$ & Reduction \% \\
\hline Check & - & - & $14.31^{a}$ & - \\
\hline 15 June & 15 & Tillering & $14.28^{\mathrm{a}}$ & 0.21 \\
\hline 30 June & 30 & Maximum tillering & $10.99^{b}$ & 23.20 \\
\hline 15 July & 45 & Panicle initiation & $8.64^{b c}$ & 39.62 \\
\hline 30 July & 60 & Heading & $6.55^{c}$ & 54.23 \\
\hline 30 June +15 July & $30+45$ & Max. tillerin + panicle init. & $2.18^{d}$ & 84.77 \\
\hline 15 July +30 July & $45+60$ & Panicle init. + heading & $2.96^{d}$ & 79.32 \\
\hline Carbofuran (6 kg/feddan) & $15+45$ & Tillering + panicle init. & $1.73^{d}$ & 87.91 \\
\hline
\end{tabular}

${ }^{a, b, c, d}$ Means followed by the same letter are not significantly at the $5 \%$ level of probability

\section{Results and discussion}

\section{Treatments with Trichogramma evanescens}

The egg-parasitoid, T. evanescens, was released in the rice treatment plots at the rate of $(30,000$ wasps/ feddan). The carbamate insecticide, carbofuran (Furadan $10 \mathrm{G}$ ), widely applied by rice growers, was used as for comparison check. In 2015 rice season, data in (Table 1) revealed that the parasitoid released at tillering stage, 15 days after transplanting (DAT), almost did not reduce the borer's infestation, which was evaluated as white heads (WH), 3 weeks prior to harvest. The release practiced at maximum tillering stage (30 DAT) or at panicle initiation (45 DAT) induced a moderate borer control (23.20 and $39.62 \%)$ insect infestations, respectively. However, the most efficient borer control was achieved, when the parasitoid was released twice, at maximum tillering growth stage and at panicle initiation, as the WH was reduced by (84.77\%). A similar result was obtained when the parasitoid was released at panicle initiation and at heading (79.32\% WH reduction). The application of the insecticide (carbofuran) was as efficient as the results of release at maximum tillering and at panicle initiation stages.

Depending on the results of the 2015 rice season, large-scale releases (17-20 feddans) were treated (Table 2). The parasitoid was released twice (each

Table 2 Large-scale release of Trichogramma evanescens to control the rice stem borer, Chilo agamemnon, season 2016

\begin{tabular}{|c|c|c|c|c|c|}
\hline \multirow{2}{*}{$\begin{array}{l}\text { Agricultural } \\
\text { Research } \\
\text { Station }\end{array}$} & \multirow{2}{*}{$\begin{array}{l}\text { Treated } \\
\text { area }\end{array}$} & \multicolumn{2}{|c|}{ Dead heart \% } & \multicolumn{2}{|c|}{ White head \% } \\
\hline & & Treated & Check & Treated & Check \\
\hline Sakha & 20 & 1.80 & 3.00 & 2.30 & 8.15 \\
\hline Gemmiza & 15 & 2.01 & 5.15 & 2.16 & 6.40 \\
\hline Sirw & 17 & 1.60 & 2.86 & 1.90 & 7.11 \\
\hline Average & - & 1.80 & 3.67 & 2.12 & 7.22 \\
\hline Reduction \% & & 50.95 & & 70.64 & \\
\hline
\end{tabular}

30,000 parasitoids/feddan), at maximum tillering (30 DAT) and at panicle initiation (45 DAT). Dead hearts $(\mathrm{DH})$ averaged 1.80 and $3.67 \%$ in release and non-release treatments, respectively, with a reduction of $(50.95 \%)$ in $\mathrm{DH}$. Correspondent reduction in white heads averaged (70.64\%).

The release of $T$. japonica in rice fields against rice stem borer (Chilo suppressalis Walker) and green rice semi-looper (Naragna aenescens) achieved a reduction of (77\%) in dead hearts and (29\%) in white heads, respectively, meanwhile increased the rice yield by about $11 \%$ (Asaady and Navai 1995). Similar findings were obtained by Riba and Sarma 2006) who achieved $12 \%$ rice yield increase due to the release of $T$. japonicum, at the rate of 200,000 wasps per hectare, in two or four split applications. The findings of Kaur and Brar (2008) and Ko et al. (2014) indicated that Trichogramma releases might be considered practical for the control of the striped stem borer, $C$. suppressalis. In paddy field trials, the release of T. japonicum reduced the stem borer infestation by $9 \%$, while $T$. chilonis reduced it by $15 \%$, without significant differences among 50,000, 100,000, or 200,000 wasps/hectare (Tang et al. 2017).

The present study revealed the efficacy of $T$. evanescens as a bio-agent against the rice stem borer, $C$. agamemnon. Similar results were obtained by Sherif et al. (2008) who achieved borer infestation reduction of $25-71 \%$ due to the release of the same parasitoid, at rates ranged between 10,000 and 50,000 wasps/feddan.

\section{Treatments with silica}

Throughout the two seasons of 2015 and 2016, rice stem borer infestation was evaluated as white heads' percent that averaged $9.39 \%$ in the check (untreated) plots (Table 3). All forms of silica tested against the pest achieved moderate control, as they reduced the white heads by (52.50-58.25\%). Accordingly, the silica applications could be used to reduce the infestation of the rice 
Table 3 Influence of silica materials application on the rice stem borer, Chilo agamemnon, infestation, assessed as percentages of rice plant white heads

\begin{tabular}{|c|c|c|c|c|c|}
\hline Treatment & Rate/feddan & 2015 & 2016 & Average & Reduction \% \\
\hline Check (without) & - & $11.63^{\mathrm{a}}$ & $7.15^{\mathrm{a}}$ & 9.39 & - \\
\hline Compost straw (basal) & $2.1 \mathrm{t}$ & $9.58^{\mathrm{b}}$ & $6.58^{\mathrm{b}}$ & 8.08 & 13.95 \\
\hline Mixed mineral (basal) & $500 \mathrm{~kg}$ & $4.85^{\mathrm{C}}$ & $3.92^{c}$ & 4.39 & 53.25 \\
\hline Potassium silicate (basal) & $500 \mathrm{~kg}$ & $4.14^{\mathrm{C}}$ & $3.69^{c}$ & 3.92 & 58.25 \\
\hline Biocide ore (two sprays) & 2 kg spray & $4.88^{c}$ & $4.04^{c}$ & 4.46 & 52.50 \\
\hline Magnesium silicate (two sprays) & 2 kg spray & $4.30^{c}$ & $4.28^{\mathrm{c}}$ & 4.29 & 54.31 \\
\hline
\end{tabular}

$\overline{a, b, c}$ Means followed by the same letter are not significantly at the $5 \%$ level of probability

stem borer, C. agamemnon. Monocotyledons, including rice, are categorized as high accumulators of silica (Liang et al. 2007), and the straw of rice plants may contain about 4.8-13.5\% silica (Nayar et al. 1982). Several investigators applied silica to rice soils to enhance rice tolerance to biotic and abiotic stresses. Adding different forms of silica to the soil increased the resistance of rice plants to stem borers (Vasanthi et al. 2014). Chandramani et al. (2010) found that the occurrence of stem borer had a highly significant negative correlation with silica $(-0.930)$. Many authors studied and explained the mechanism of silica against the insects feeding upon plants with high levels of such element. Epstein (1994) concluded that the silica accumulated and deposited in epidermal cells of rice tissues that act as a barrier against pest invasion to the plants. In an experiment, where fly ash (high silica content) was applied to the soils of rice, Chandramani et al. (2010) attributed the main cause of insect mortality to the wearing of mandibles and other feeding organs of the insects, which results in failure of the normal feeding upon rice plants. This phenomenon is in parallel with the result of Vasanthi et al. (2014) who found that silica is deposited as $2.5 \mathrm{~mm}$ layer under the cuticle, forming additional defense mechanism against the invading insects.

The effect of silica deposited in plant tissues could be complementary with the role of natural enemies in suppressing the damage caused by insect pests. Because the silica barriers delay the invasion of insects to plant tissues, the retarded insects become more exposed to their parasitoids and predators. On the other hand, the delayed invasion renders the insect pests exposed to unfavorable environmental conditions or oblige these pests to feed upon less preferred plant hosts (Reynolds et al. 2009).

\section{Conclusion}

It could be concluded that release of egg parasitoid, $T$. evanescens, in rice fields at a maximum tillering growth stage (30 days after transplanting) and at panicle initiation, at the rate of 30,000 wasps/feddan, could achieve an efficient control against the rice stem borer, C. agamemnon. In addition, applying materials, with high silica contents in rice fields either as soil incorporated or spray on rice foliage, can also reduce the infestation levels. Further studies are required to test the combined applications of silica materials and biological control agents.

\section{Acknowledgements \\ Not applicable. \\ Funding \\ The research had no sources of funding.}

Availability of data and materials

All datasets are presented in the main manuscript.

Authors' contributions

All authors read and approved the final manuscript.

Ethics approval and consent to participate

Not applicable

\section{Consent for publication}

Not applicable

\section{Competing interests}

The authors declare that they have no competing interests.

\section{Publisher's Note}

Springer Nature remains neutral with regard to jurisdictional claims in published maps and institutional affiliations.

\section{Author details}

${ }^{1}$ Plant Protection Research Institute, Agricultural Research Center, Giza, Egypt ${ }^{2}$ Field Crops Research Institute, Agricultural Research Center, Giza, Egypt.

${ }^{3}$ Faculty of Agriculture, Kafr El-Sheikh University, Karf El Sheikh, Egypt.

Received: 1 May 2018 Accepted: 21 October 2018

Published online: 28 November 2018

\section{References}

Asaady, H. B. and I. N. Navai (1995). Effects of rearing conditions on the efficacy of Trichogramma against rice stem borer (Chilo suppressalis) and green rice semi-looper (Naragna aenescens) in Mazandaran. Trichogramma News, 28:33

Chandramani P, Rajendran R, Muthiah C, Chinnaiah C (2010) Organic source induced silica on leaf folder, stem borer and gall midge population on rice field. J Biopesticides 3:423-427

Duncan DB (1955) Multiple range and multiple F tests. Biometrics 11:1-42

Epstein E (1994) The anomaly of silicon in plant biology. Proc Natl Acad Sci U S A 91:11-17 
Kaur R, Brar KS (2008) Evaluation of different doses of Trichogramma species for the management of leaf folder and stem borer on basmati rice. J Biol Control 22:131-135

Ko K, Liu Y, Hou M, Babendreier D, Zhang F, Song K (2014) Evaluation for potential Trichogramma (Hymenoptera: Trichogrammatidae) strains for control of the striped stem borer (Lepidoptera: Crambidae) in the Greater Mekong Subregion. J Econ Entomol 107:955-963

Liang Y, Sun W, Zhu Y, Christie P (2007) Mechanisms of silicon mediated alleviation of abiotic stresses in higher plants: a review. Environ Pollut 147: $422-428$

Marub F (1993) YRSB eggs parasitoid potential to different rice varieties in an IPM. Ilum Pertania 5:645-656

Nayar PK, Mishra AK, Patnik S (1982) Silica in rice and flooded rice soils. I. Effects of flooding on the extractable silica in soil and its relation with uptake by rice. Oryza 19:34-40

Reynolds OL, Keeping MG, Meyer JH (2009) Silicon augmented resistance of plants to herbivorous insects: a review. Ann Appl Biol 155:171-186

Riba T, Sarma AK (2006) Efficacy of Trichogrmma japonicum Ashmead against yellow stem borer, Scirpophaga incertulas Walk. on rice in Nagaland. J. Appl. Zool Res 17:196-200

Sherif, M. R. and Amany S. El-Hefny (2014). Natural enemies in rice as influenced by weed removal of bio, and chemical insecticide applications. Annals of agric. Sci., Special Issue, 59: 407-418

Sherif MR, Hendawy AS, El-Habashy MM (2008) Utilization of Trichogramme evanescens for controlling rice stem borer, Chilo agamemnon Bles. in rice fields in Egypt. Egypt J. Biol. Pest Control 18:11-16

Tang R, Babendreier D, Zhang F, Kang M, Song K, Hou M (2017) Assessment of Trichogramma japonicum and T. chilonis as potential biological control agents of yellow stem borer in rice. Insects 8:1-12

Tisdale SL, Nelson WL, Beaton JD (1985) Soil fertility and fertilizers. MacMillan Publ, Newyork, p 754

Vasanthi N, Saleena LM, Raj SA (2014) Silicon in crop production and crop protection - a review. Agri Rev 35:14-23

\section{Submit your manuscript to a SpringerOpen ${ }^{\circ}$ journal and benefit from:}

- Convenient online submission

- Rigorous peer review

- Open access: articles freely available online

High visibility within the field

- Retaining the copyright to your article

Submit your next manuscript at $\boldsymbol{\nabla}$ springeropen.com 